\title{
A Project to Improve the Employability Skills of Postgraduate ICT Students through Workplace Cultural Awareness
}

\author{
Dale Mackrell \\ Griffith University, Brisbane, QId, Australia
}

\section{d.mackrell@griffith.edu.au}

\begin{abstract}
In this working paper, the author proposes that the employability of domestic and international postgraduate information and communication technology (ICT) students can be enhanced through a project in which workplace organizational and cross-cultural awareness is embedded. The genesis of the paper, which focuses on a review of the literature, is a learning and teaching grant application, the overriding aims of which are to address at assessment level the strategic priority areas for an Australian university. The proposed project consists of an assessment requiring the formation of small intercultural student teams as described in this paper. While the assessment is designed for a subject in a coursework Masters in the information systems (IS) field of the university business school, the model if successfully deployed, may be transferable to other tertiary subjects and programs. Outcomes of the project are expected to include: 1) enduring relationships with industry; 2) work-ready graduates with a more professional attitude to employment, a respect for cultural and linguistic diversity, and an appreciation for life-long learning; and 3) the dissemination of findings in research publications.
\end{abstract}

Keywords: Assessment, organizational culture, domestic students, international students, postgraduate, work-integrated learning, information and communication technology.

\section{Introduction}

The project is based on the research question, "How can the learning experiences of domestic and international students be improved so that they are better prepared for the global workplace?". The project aims to address the strategic priority areas for Griffith University, situated in Brisbane Queensland. In particular, the strategic objectives are to improve "the attractiveness of postgraduate programs" while embedding "career information in program structures" with the aim of developing "internationally recognised professionals, capable of engaging in professional practice in a variety of contexts both within and beyond their country of origin or domicile" (Griffith University, 2007a, p.3; 2007b, p.2). Likewise, the project is driven by the recent Bradley Review

Material published as part of this publication, either on-line or in print, is copyrighted by the Informing Science Institute. Permission to make digital or paper copy of part or all of these works for personal or classroom use is granted without fee provided that the copies are not made or distributed for profit or commercial advantage AND that copies 1) bear this notice in full and 2) give the full citation on the first page. It is permissible to abstract these works so long as credit is given. To copy in all other cases or to republish or to post on a server or to redistribute to lists requires specific permission and payment of a fee. Contact 0HPublisher@InformingScience.org to request redistribution permission. which identified that Australia's higher education system needs the capacity to "provide students with a stimulating and rewarding higher education experience" and to "meet the needs of the labour market and industry for high level skills" in order to "operate internationally" (Bradley, Noonan, Nugent and Scales, 2008, p.2). 
Education services are Australia's third-largest export industry (Bradley et al., 2008) while information and communication technology (ICT) is a major driver of Australia's economic growth and productivity (DCITA, 2006). The term, information and communication technology (ICT) in this paper refers to both information systems (IS) and information technology (IT).

Internationalization is defined as "the process of integrating an international, intercultural or global dimension into the purpose, functions, or delivery of post secondary education" (Griffith University, 2007b, p.1). The Internationalization Strategy at Griffith University provides a framework for teaching, learning, and research in a determination to strengthen the University's international standing and reputation. At Griffith University, this strategic objective is well underway with nearly $25 \%$ of the student body from overseas and $40 \%$ of the academic staff born overseas (Griffith University, 2007b). While the numbers vary each year, the majority of overseas students studying in Australia are from Asia-Pacific countries such as China, Hong Kong, Taiwan, Korea, Japan, Singapore, and the Philippines, Middle Eastern countries such as Saudi Arabia and Oman, and most numerously India, Pakistan and Sri Lanka. There are a lesser number of students from Scandinavian nations and South America. The majority of international students are enrolled in ICT and accounting subjects (International Students Studying in Australia, n.d.).

An operational response to the above strategies is a proposed research project at subject assessment level in which is embedded the tools for students to directly access career information from industry. For the assessment, postgraduate students, in small intercultural teams, will be required to interview Australian business employers from ICT-intensive organizations regarding their expectations of graduates and to report their findings in group presentations and written reports. The aim is that postgraduate students enrolled in the Master of Information Systems (IS) by coursework can be better prepared for the workplace by developing both context-specific disciplinary knowledge (frequently referred to as 'hard' or technical skills) and broader generic attributes (frequently referred to as 'soft' or non-technical skills). It is generally agreed that a combination of 'soft' and 'hard' skills is needed. This was acknowledged by Senator Coonan when launching a program to promote the international competiveness of the Australian ICT professional (DCITA, 2006, p.51).

The hallmarks of the ICT professional will soon include creative, interpersonal and project management skills, as well as expertise in specific areas such as health, and education, and the ability to effectively mesh hard and soft skills.

The subject content will be designed to prepare students for the assessment task. Students will learn key generic graduate skills, engage with their specific disciplinary learning integrated within an intercultural and organizational perspective, and be encouraged to reflect critically on their goals. This project represents a link between the theory learnt at university and the practical context of industry, and may have transferability to related subjects and programs across the university.

The structure of this paper is as follows. Firstly, a review of the relevant literature is presented providing various pedagogical views on issues such as requisite graduate skills, the emerging prominence of globalization and cultural awareness in education, employability criteria, and work-integrated learning, particularly within the ICT context. Then, the design of the proposed assessment using curricula discourse is described and justified. Next, the outcomes and deliverables of the project are given. Finally, the distinctiveness of the project as well as its contributions to literature and practice are explained. 


\section{Review of the Literature}

The project has the potential to revive flagging local interest in ICT studies. Reviews of literature from government, industry, and academic sources identify that the nature of ICT employment in Australia is changing and that the ICT industry currently suffers from spiralling low numbers of suitably skilled employees (DCITA, 2006; Foreshew, 2007; Mackrell, 2009). Increasing ICT skills shortages in Australia has led to the immigration of overseas workers with the relevant skill sets to augment the supply. This trend is expected to intensify if Australia continues to espouse the fast-growth strategy where skilled immigrants replace retiring 'boomers' to meet labour market demands, as projected by Australian demographer Salt (2009, pp. 29-30). As well, the offshoring and outsourcing of ICT work to other countries has exacerbated the problem for Australian domestic students who perceive poor recruitment opportunities and ill-defined career paths, thus leading to a continuing decline in ICT enrolments. All the same, Australian universities are encouraging students, both domestic and international, to enrol in postgraduate ICT programs such as the Masters of Information Systems (MIS), the Masters of Information Technology (MIT), and the Masters of Business Administration (Information Systems) (MBA). As well, many computing departments in Australian universities are undergoing diverse restructuring, reviews, and accreditations in efforts to capture new market share and increase student numbers (Tan and Venables, 2008).

\section{Graduate Skills}

The project is a direct response to the findings of a recent pilot study which found that students in the MIS program of the Business School at Griffith University are appreciative of the flexible learning environment which encourages independent learning but are keen to have contact with Australian businesses in order to better comprehend Australian business culture (Author, 2009). On the flip side, ICT university graduates everywhere reportedly lack requisite employment knowledge and skills and are ill-equipped for the workforce (DCITA, 2006; Kim, Hsu and Stern, 2006).

Generic graduate skills for the Australian workplace have been identified and documented extensively by Curtis and McKenzie (2001) in their report commissioned by the Australian Council for Educational Research (ACER) while Griffith University (2009b) specifies graduate skills to be effective oral and written communication, critical and creative thinking, problem solving, autonomous and collaborative work, socially responsible behaviour, competence in global contexts as well as discipline knowledge and skills. The value of competence in global contexts was made clear when the Chairman of the Australian Computer Society (Parakala, 2009, p.31) appealed for technical professionals to "take a global perspective" when planning careers by "education and training to develop an understanding of international trends".

The findings of recent research reflect the business and technology pedagogical debate, emphazising the need for balancing a business perspective in ICT educational programs. In the USA, studies have established requisite graduate knowledge and skills for employment in computer-intensive industries (Aasheim, Li and Williams, 2009; Bullen, Abraham and Galup 2007) with high premiums placed on the acquisition of high-order employability skills, including the ability to self-manage careers. This quality is increasingly important in a changing world since managing life-long learning is essential for adapting to shifting professional and social experiences.

Standardised curricula have been developed for the education of students in the necessary skills and knowledge for ICT careers. One of these curriculum models is the MSIS 2006 which was developed by a joint task force of the Association for Information Systems (AIS) and the Association for Computing Machinery (ACM) to provide guidelines for graduate degree programs in 
IS (Gorgone, Gray, Stohr, Valacich and Wigand, 2006). The MSIS 2006 document refers to the 'sliding window' strategy which is the continuum of subjects ranging from foundational to advanced. The purpose of this 'window' is to accommodate and support the varied backgrounds of the students and their career paths: consulting, data management, project management, software development, to name but a few (Gorgone et al., 2006, pp. 9-12).

Interpreting the underlying trends in Gorgone et al. (2006) and taking into consideration the globalization factor, Abraham, Beath, Bullen et al. (2006) found that the traditional programmeranalyst-manager career path is no longer the norm in many organizations. It is being replaced with the trainee-liaison-business analyst-project manager track underscoring client-facing and managerial skills in addition to solid technical foundations. There is an increasing tendency in organizations for technical capabilities to be externally sourced although they are still in demand for entry-level hires. However experiential learning integrated in curricula is becoming crucial (Bullen, Abraham and Gallup, 2007).

\section{Cultural awareness}

An appreciation of culture, both cross-cultural and organizational, has implications for graduates, educators, and employers alike. Burke and Litwin (1992, p.526) define organizational culture as "the collection of overt and covert rules, values, and principles that are enduring and guide organizational behaviour". Debuse and Lawley (2009) from the University of the Sunshine Coast in Queensland found that Australian employers are seeking graduates with the ability to think critically and have acquired some industry experience. Concerns regarding insights into organizational culture are replicated in other disciplines beyond ICT. An Australian study in the field of accounting by Kavanagh and Drennen (2008) of student and employer perceptions of requisite graduate attributes found large disparities between the expectations of students, academics and employers. An USA study in health by Van Ess Coeling (1990) called attention to the adjustment of new nursing graduates to the workplace through the incorporation of organizational cultural awareness into the curriculum.

The call for intercultural knowledge and skills training is well documented (Clark 2008). Cant (2004) in the USA and Litchfield, Nettleton and Taylor (2008) in Australia assert that students need both disciplinary knowledge and intercultural understandings in preparation for the "realities of global commerce" (Cant 2004, p.180). The ExcelL program (Excellence in Cultural Experiential Learning and Leadership) was co-developed by Professors Michelle Barker and Anita Mak for fostering intercultural skills training for international students. It consists of six distinct stages to progress participants from initial contact to being able to use the skills in crosscultural settings (Woods and Barker, 2003). Barker (2006, pp.1-2), in describing the role of ExcelL, states that, in Australia, overseas students encounter "language and cultural barriers in transferring their skills to mainstream workplaces ... their lack of local work experience further confers a substantial disadvantage in job search ... and could hinder effective participation in groups at work or educational settings". According to Barker, Troth and Mak (2002), ExcelL is ideal for initiating international students to the underlying values which influence behaviours in Australian society.

International studies advocate the attainment of 'cultural intelligence', considered an imperative for fomenting cultural sensitivity skills, and enabling graduates to adapt rapidly to fresh crosscultural situations (Blasco, 2009). According to Blasco (2009, p.177), 'cultural intelligence' combines three main dimensions: 1) knowledge of culture and its affect on manifest behaviour; 2) mindfulness or sensibility to cultural signals; and 3) behavioural skills from a combination of knowledge and mindfulness.

People with cultural intelligence are supposed to look beyond the cultural stereotypes to "interact effectively across cultures" (Thomas and Inkson, 2005 p.7), displaying respect and moral probity 
(Blasco, 2009). Biggs (2003) argues that cultural stereotypes are merely perceptions and that educators need to be active in employing teaching strategies to overcome inherent difficulties in culturally diverse classrooms while Walker and Jeurissen (2003) declare that the challenge for educators is to prepare students for increasingly culturally diverse workplaces. This is supported by Jones (2003) who claims that cultural awareness is most effectively learnt by students through experiential exposure to cross-cultural situations. Yet, overall, university teaching emphazises the theoretical dimensions of culture rather than the practical.

\section{Employability}

The concept of graduate 'employability' is complex. While the core notion is to obtain a job, Harvey (2001) emphazises that employability is often construed as an institutional achievement without taking into account the propensity of students to find employment and the efforts of employers to convert employability into employment. Cranmer (2006) puts forward the argument that employability outcomes are confused and can overlook social structures of gender, race, and class and their interactions with the labour market. Furthermore, operationalising employability from a theoretical concept to a measurement depends on the definition of employability (Harvey, 2001 p.100). Cranmer (2006) states that despite the best intentions of academics, it is unrealistic to expect universities to guarantee that students will possess both the necessary generic and disciplinary skills on graduation and that more positive employability outcomes are reported when employers are involved in academic subjects. Nonetheless, as Litchfield et al. (2008) explains, generic skills are often left to the universities to teach because employers find training new graduates in employability skills too difficult.

Universities are responding to growing challenges by re-evaluating graduate professional learning objectives and outcomes with curriculum design and renewal (Litchfield et al., 2008). In efforts to heed the call for improved student experiences and graduate employability, many subjects and programs at Griffith University such as the undergraduate-level Professional Development (PD) program have Work-integrated Learning (WIL) components embedded within them. WIL is the term used to describe educational activities that integrate theoretical learning with its application in the workplace. Studies have found that the integrated WIL model contributes substantially to building and improving the professional identities of students and increases their awareness of the skills needed to be a professional (Freudenberg, Brimble \& Cameron, in press). WIL is known by other terms. Brockbank and McGill (1998, p.217) refer to action learning which they describe as a "group-based approach to learning". Although the origins of WIL are not new, the experiential approach to learning has only recently spread from vocational institutions to universities and many studies endorse the value of team work (Brockbank and McGill, 1998, p.167). Learning the rules or guidelines for coping with group dynamics in a safe university environment is valuable preparation for an increasing number of industry workplaces. All the factors affecting graduate employability conflate in the proposed assessment item described in the next section.

\section{Proposed Assessment Design}

The curriculum response to the strategic priorities discussed is proposed in the form of a research project where postgraduate students, in small intercultural teams, are required to engage with industry and then present their findings. The project is an assessment item in a subject such as Information Systems Analysis within a Master of Information Systems (MIS) program and is worth $50 \%$ of the assessment marks of the subject. Information Systems Analysis is a semester-long subject in which students are introduced to the tools, techniques, and methodologies required by systems and business analysts. While the proposed assessment is neither subject- nor programspecific, it was selected since it contains suitable topics such as requirements gathering, planning and communication wherein students are taught theory associated with the collection and analysis 
of information from users (Sidorova, 2009). Critical graduate employability skills (both generic and disciplinary) will be woven into the subject content and explicitly assessed (Cranmer 2006, p.172).

Biggs (2003, p.141) emphazises the importance of constructive alignment, that is, there needs to be alignment between assessment, curriculum, teaching methods and institutional aims. Principally, assessment tasks should comprise a genuine representation of subject objectives. Furthermore, Biggs (2003) claims that the existence of assessment motivates students to attend classes.

The proposed assessment item builds on existing projects at Griffith University such as WIL and ExcelL. To differentiate, this assessment is a research project which incorporates the principles of ExcelL and can be deemed preparation for the WIL experience or for genuine placement in the workplace, irrespective of whether students choose to return to their home country or to seek employment in Australia. The assessment item is also expected to provide a relevant and practical business context for the application of theory learnt in an academic setting and thus encourages and reinforces student learning.

The project teaching team, consisting of the teaching staff, has assigned tasks through the semester. Refer to Table 1 for details. It is their responsibility to engage with industry early in the semester and prepare the requirements of the assignment, as well as to evaluate the project success and to disseminate the findings as conference and journal publications, and possible workshops.

Table 1: Proposed Semester Tasks for the Project Teaching Team

Recruit approximately 8 to 10 industry employers for an anticipated class of 25-30 students. Establish frameworks for student mentoring and industry liaison. Prepare and submit project ethics clearance to university for approval.

Conduct interviews with industry participants prior to student interviews to identify organizational context and employer expectations of graduates using indicators of key graduate attributes - industry interview \#1.

Transcribe and analyze the interview data. Prospective software tools are SurveyMonkey.com and Leximancer (www.leximancer.com) for text mining.

Prepare the questionnaire/survey sheet with both qualitative and quantitative aspects to be used as an interview guide/framework by the students. Prepare the preliminary findings to be used as reference points/marking criteria framework against which the students' projects will be assessed.

Design the subject content used to prepare students for the assessment tasks. Students to learn key generic graduate skills, engage with their specific disciplinary learning integrated within an intercultural perspective, and be encouraged to reflect critically on their goals. Teach generic skills supported by Toolkits for Teaching Students Graduate Skills (Griffith University, 2009c). See Cranmer (2006, p.172) re explicit embedding of employability skills in curriculum.

Mark the assessment item which has a value of $50 \%$ of the subject marks against developed marking criteria framework. See Cranmer (2006, p.172) and Harvey (2001, p.100) re explicit assessing of students' employability abilities. Provide feedback to students on results.

Prepare evaluations. Students to assess subject content and delivery. Industry stakeholders to assess student and project teaching team performances - industry interview \#2. Analyze data.

Disseminate the findings as conference and journal publications, and possibly workshops.

Students in small teams are required to directly engage with industry using an interview script prepared by the project teaching team. The assessment tasks of the student teams and the expected outcomes are listed in more detail in Table 2. 
Table 2: Proposed Assessment Tasks for Student Teams

\begin{tabular}{|l|l|}
\hline Student Team Tasks & Tasks Outcomes \\
\hline $\begin{array}{l}\text { Form groups of } 3 \text { to } 4 \text { students generally of a } \\
\text { cross-cultural nature with assistance from } \\
\text { teaching staff on request. }\end{array}$ & $\begin{array}{l}\text { This task introduces students to cultural and } \\
\text { language diversity. }\end{array}$ \\
\hline $\begin{array}{l}\text { Interview industry contacts using the ques- } \\
\text { tionnaire/survey sheet developed as an inter- } \\
\text { view framework by the project teaching team } \\
\text { to explore organizational culture and employ- } \\
\text { ers expectations of graduates - industry inter- } \\
\text { view \#3. }\end{array}$ & $\begin{array}{l}\text { This task requires a range of student graduate } \\
\text { skills such as effective work collaboration } \\
\text { and competence in a culturally and linguisti- } \\
\text { cally diverse environment. As well, students } \\
\text { have contact with Australian business cul- } \\
\text { tures. }\end{array}$ \\
\hline $\begin{array}{l}\text { Transcribe and analyze the data gathered in } \\
\text { the interviews. }\end{array}$ & $\begin{array}{l}\text { This task requires a range of student graduate } \\
\text { skills such as the ability to problem solve and } \\
\text { think analytically. }\end{array}$ \\
\hline $\begin{array}{l}\text { Report the research findings in a written report } \\
\text { with a reflective log component as well as a } \\
\text { group presentation to which industry contacts } \\
\text { would be invited. }\end{array}$ & $\begin{array}{l}\text { This task requires a range of student graduate } \\
\text { skills such the ability to think critically and } \\
\text { creatively along with effective oral and writ- } \\
\text { ten communication and academic integrity. }\end{array}$ \\
\hline $\begin{array}{l}\text { Provide feedback on subject content and de- } \\
\text { livery. }\end{array}$ & $\begin{array}{l}\text { See Harvey and Knight (1996, p.80) re the } \\
\text { validity and reliability of teaching evaluations } \\
\text { by students. }\end{array}$ \\
\hline
\end{tabular}

The estimated timeline for developing and implementing the activities of the project by the project teaching team and student teams is set out in Table 3.

\begin{tabular}{|l|l|}
\hline \multicolumn{2}{|c|}{ Table 3: Estimated Timeline of Tasks by Project Teaching Team } \\
\hline Timeline & Tasks \\
\hline $\begin{array}{l}\text { October-December } \\
\text { January-February 2011 }\end{array}$ & $\begin{array}{l}\text { Recruit employers as study participants } \\
\text { Recruit research assistant for data analysis } \\
\text { Prepare and submit project ethics clearance to university } \\
\text { Write subject outline to include assessment item }\end{array}$ \\
\hline $\begin{array}{l}\text { Commence employer interviews - industry interviews \#1 } \\
\text { Analyze data and create interview framework for students }\end{array}$ \\
\hline March 2011 & $\begin{array}{l}\text { Commence semester teaching } \\
\text { Form student teams }\end{array}$ \\
\hline April-May 2011 & $\begin{array}{l}\text { Students to interview using prepared interview script, analyze data, } \\
\text { present and report findings - industry interviews \#3) } \\
\text { Carry out range of student evaluations of project } \\
\text { End semester teaching }\end{array}$ \\
\hline June 2011 & Finalise assessment marks \\
\hline July-August 2011 & $\begin{array}{l}\text { Re-interview employers including evaluations - industry interviews } \\
\text { \#2 } \\
\text { Analyze data }\end{array}$ \\
\hline $\begin{array}{l}\text { September-December } \\
\text { 2011 }\end{array}$ & $\begin{array}{l}\text { Write papers and disseminate findings } \\
\text { Modify subject for following semester/year based on evaluations }\end{array}$ \\
\hline
\end{tabular}


Evidence of the successful impact of the assessment are expected to be: 1) requests by educators to deploy the project concept to other subjects and programs; 2) willingness by business employers to participate in subsequent subjects; and 3) constructive evaluations by both students and business contacts. The strategies for evaluating the project would incorporate assessing formally and informally by students (for example, student reflective logs as a component of the research report would be submitted and analyzed) and employers (for example, industry stakeholder appraisals would be gathered either face-to-face or electronically by the project teaching team following student interviews) as qualitative and quantitative data.

\section{Expected Outcomes and Deliverables}

The proposed subject assessment item is an operational response to strategic aims. The proposed project has the capacity to improve the learning experiences of domestic and international postgraduate students, particularly in the ICT field, and has the potential to boost the key employability skills of graduates. This approach to learning is student-centred allowing students to explore, problem-solve, and reflect in small cross-cultural teams.

Two main outcomes of the project are expected from the project: 1) motivated graduates who are well prepared for the workforce and/or WIL with competence in intercultural and selfmanagement skills, and realistic perceptions of employer expectations; and 2), establishment of a bank of enthused employers willing to participate in the project in the future through the establishment of dialogue between educators and industry.

Several deliverables are expected from the project: 1) subject content for student acquisition of generic graduate skills as well as more specific business and technical disciplinary knowledge, shaped for culturally and linguistically diverse students by drawing on ExcelL and WIL principles; 2) subject content to assist students to undertake research by conducting a basic literature review, interviewing employers, transcribing and analysing data, and presenting the findings; 3 ) detailed requirements for the assessment as a research project will be developed; and 4) frameworks will be established for student mentoring, industry liaison, interviewing and marking. The relationship management role concerning students and employers is expected to be performed by the project teaching team members. Lastly, the writing up and submission of findings in conference papers and journal articles will be carried out by the project teaching team members.

\section{Conclusion}

The proposed assessment will introduce postgraduate students to Australian businesses and to the expectations of employers with the aim of enhancing career prospects by direct experiential exposure to cross-cultural and workplace situations. In this section, issues such as the innovativeness of the project and its conjectured transferability to other subjects and programs are discussed.

WIL and ExcelL activities are well entrenched in various disciplines at Griffith University. Yet, this project is innovative and distinctive because:

1. Many WIL activities target undergraduate students. Lees (2002, p.7) states, "postgraduates are rarely mentioned in the literature concerning the development of employability skills and abilities". This project is aimed at domestic and particularly international postgraduate students who would benefit from contact with Australian businesses and their unique organizational culture. Domestic postgraduate students who are presently in employment would benefit from the cultural and linguistic diversity aspects of the project.

2. WIL activities are generally for individual students (Freudenberg et al., in press). This assessment item requires team work. 
3. This project would encourage participation by international students in social settings by adopting some suitable stages from the ExcelL program. Walker and Jeurissen (2003) found on-line communication tools facilitated the sharing of knowledge and increased interaction amongst students, in that this particular means of communication empowers more reticient students, especially the Asian participants, to express their views. Hence, it is proposed that subjects should incorporate on-line discussions forums or wikis enabling the students to work in virtual teams, possibly with a graded component to encourage and ensure participation.

4. The proposed assessment item is not costly in human resource terms. Once the frameworks and subject content are in place, subject convenors or their appointees can facilitate. Brockbank and McGill (1998, p.166) encourage the facilitation stance to teaching since it leads to "reflective and critical learning in students" as distinct from the more didactic approach inherent in traditional lecturing.

5. As apparent from the literature review, there is a plethora of studies where research is conducted by educators who contact industry participants. In this project, the students are required to talk with potential employers.

6. Consequently, the proposed assessment item can be considered as preparation for WIL activities or genuine employment.

At Griffith University, the Academic Plan 3: Learning for Success (2007a) specifies that $70 \%$ of Griffith programs must have an identifiable WIL component by 2010. While the assessment does not replace industry placement, it does provide a specific vocational experience to prepare the student for the WIL experience. With the frameworks in place, the assessment can be managed by the subject convenor or substitute. As already stated, the proposed assessment model, can potentially be re-deployed beyond the Masters of Information Systems (MIS) program to various programs such as Masters of Information Technology (MIT) and Masters of Business Administration (MBA).

This paper outlines the proposal for the assessment project. The next step is to carry out the proposal by conducting the project, evaluating its success, and writing up the findings. The project research is expected to contribute meaningfully to the body of literature which explores learning and teaching in higher education settings. At a practical level, this project is expected to contribute usefully to the workplace preparation of postgraduate students, increasing their cognitive engagement with the theory learnt at university.

\section{References}

Aasheim, C., Li, L., \& Williams, S. (2009). Knowledge and skill requirements for entry-level information technology workers: A comparison of industry and academia. Journal of Information Systems Education, 20(3), 349-356.

Abraham, T., Beath, C., Bullen, C., Gallagher, K., Goles, T., Kaiser, K., \& Simon, J. (2006). IT workforce trends: Implications for IS programs. Communications of the Association for Information Systems, 17(Article 50), 1-44.

Barker, M. (2006). Newcomers and hosts: The role of intercultural skills training in promoting social integration. Retrieved September 2009 from http://www.conferences21.com/UserFiles/File/Michelle\%20Barker\%20\%20Intercultural\%20Skills\%20Training\%20In\%20Promoting\%20Social\%20Integration.pdf

Barker, M., Troth, A., \& Mak, A. (2002). Transition to a new academic context: Intercultural skills training for international postgraduate students. Paper presented to 10th Post Compulsory and Education Training Conference, Gold Coast Australia. 
Biggs, J. (2003). Teaching for quality learning at university (2nd ed.). Berkshire, UK: The Society for Research into Higher Education and Open University Press, McGraw-Hill Education.

Blasco, M. (2009). Cultural pragmatists? Student perspectives on learning culture at a business school. Academy of Management Learning and Education, 8(2), 174-187.

Bradley, D., Noonan, P., Nugent, H., \& Scales, B. (2008). Review of Australian higher education. [Discussion paper. June 2008]. Retrieved September 2009 from http://www.dest.gov.au/NR/rdonlyres/06C65431-8791-4816-ACB96F1FF9CA3042/22465/08 222 Review AusHEd Internals 100pp FINAL WEB.pdf

Brockbank, A., \& McGill, I. (1998). Facilitating reflective learning in higher education. Buckingham, UK: The Society for Research into Higher Education and Open University Press.

Bullen, C., Abraham, T., \& Galup, S. (2007). IT workforce trends: Implications for curriculum and hiring. Communications of the Association for Information Systems, 20(Article 34), 545-548.

Burke, W., \& Litwin, G. (1992). A causal model of organizational performance and change. Journal of Management, 18(3), 523-545.

Cant, A. (2004). Internationalizing the business curriculum: Developing intercultural competence. The Journal of American Academy of Business, 5, 177-182.

Clark, A. (2008). International ICT students get help finding jobs down-under. Retrieved July 2009 from http://www.itnews.com.au/News/112207,international-ict-students-get-help-finding-jobs-downunder.aspx

Cranmer, S. (2006). Enhancing graduate employability: Best intentions and mixed outcomes. Studies in Higher Education, 31(2), 169-184.

Curtis, D., \& McKenzie, P. (2001). Employability skills for Australian industry: Literature review and framework development. Australian Council for Educational Research (ACER) Report to Business Council of Australia and Australian Chamber of Commerce and Industry, December 2001. Retrieved October 2009 from http://www.dest.gov.au/NR/rdonlyres/4E332FD9-B268-443D-866C621D02265C3A/2212/final report.pdf

DCITA. (2006). Building Australian ICT skills: Report of the ICT skills foresighting working group. Australian Government, Department of Communications, Information Technology and the Arts, March 2006. Retrieved October 2009 from http://www.archive.dcita.gov.au/2007/12/ict_skills_foresighting_working_group

Debuse, J., \& Lawley, M. (2009) Desirable ICT graduate attributes: Theory versus practice. Journal of Information Systems Education, 20(3), 313-326.

Foreshew, J. (2007, November 13). No graduate relief for tech skills squeeze: Offshoring contributes to an impression that there's no career for Aussies in IT. The Australian IT, p.31.

Freudenberg, B., Brimble, M., \& Cameron, C. (in press). Where there is a WIL there is a way. Asia Pacific Journal of Cooperative Education (APJCE) and Higher Education Research Development (HERD).

Gorgone, J., Gray, P., Stohr, E., Valacich, J., \& Wigand, R. (2006). MSIS 2006: Model curriculum and guidelines for graduate degree programs in information systems. Communications of the Association for Information Systems, 17, 1-56.

Griffith University. (2006).Definition of work-integrated learning. Retrieved October 2009 from http://www.griffith.edu.au/gihe/learning-teaching-resources/work-integrated-learning

Griffith University. (2007a). Academic Plan 3: Learning for success: A plan for student learning and success at Griffith, 2008-2010. Brisbane Qld, October 2007. Retrieved September 2009 from http://www.griffith.edu.au/about-griffith/plans-publications/academic-plan-3-learning-for-success

Griffith University. (2007b). Internationalisation strategy. Retrieved September 2009 from http://www.griffith.edu.au/_ data/assets/pdf file/0009/37476/internationalisation-strategy.pdf 
Griffith University. (2009a). Australian graduate survey. Retrieved September 2009 from http://www.griffith.edu.au/office-quality-planning-statistics/surveys/graduate-destination-survey

Griffith University. (2009b). Griffith graduate statement. Retrieved September 2009 from http://www.griffith.edu.au/gihe/learning-teaching-resources/graduate-skills-student-outcomes/griffithgraduate

Griffith University. (2009c). Toolkits for teaching students graduate skills. Retrieved October 2009 from http://www.griffith.edu.au/gihe/learning-teaching-resources/graduate-skills-student-outcomes/toolkits

Griffith University. (2009d). Griffith learning and teaching resource. Retrieved October 2009 from http://www.griffith.edu.au/gihe/learning-teaching-resources/evaluation

Harvey, L. (2001). Defining and measuring employability. Quality in Higher Education, 7(2), 97-109.

Harvey, L., \& Knight, P. (1996). Transforming higher education. Buckingham, UK: The Society for Research into Higher Education and Open University Press.

International students studying in Australia. (n.d.). Retrieved November 2009 from http://www.studiesinaustralia.com/why study in australia/international_students in australia

Jones, W. (2003). Over the wall: Experiences with multicultural literacy. Journal of Marketing Education, 25(3), 231-240.

Kavanagh, M., \& Drennan, L. (2008). What skills and attributes does an accounting graduate need? Evidence from student perceptions and employer expectations. Accounting and Finance, 48(2), 279-300.

Kim, Y., Hsu, J., \& Stern, M. (2006). An update on the IS/IT skills gap. Journal of Information Systems Education, 17(4), 395-402.

Lees, D. (2002) Graduate employability - Literature review, Retrieved November 2009 from http://www.palatine.ac.uk/files/emp/1233.pdf

Litchfield, A., Nettleton, S., \& Taylor, T. (2008). Integrating work-ready learning into the university curriculum contextualised by profession. Proceedings of the Conference for Work-Integrated Learning: Transforming Futures, October 2008, Sydney Australia.

Mackrell, D. (2009). The work readiness of master of information systems international students at an Australian university: A pilot study. Issues in Informing Science and Information Technology, 6, 179191. Retrieved from http://iisit.org/Vol6/IISITv6p179-191Mackrell653.pdf

Parakala, K. (2009, September 22). Think global in planning a career. The Australian IT, p.31.

Salt, B. (2009, October 1). Migrants key to replacing boomers. The Australian, pp.30-31.

Sidorova, A. (2009). Business analysis in information systems curriculum: Implications of business analysis professionalization. Proceedings of the 15th Americas Conference on Information Systems (AMCIS), August 2009, San Francisco CA.

Tan, G., \& Venables, A. (2008) Survival mode: The stresses and strains of computing curricula review. Journal of Information Technology Education, 7, IIP33-IIP43. Retrieved from http://www.jite.org/documents/Vol7/JITEv7IIP033-043Tan429.pdf

Thomas, D., \& Inkson, K. (2005). Cultural intelligence: People skills for a global workplace. Consulting to Management, 16(1), 5-9.

Van Ess Coeling, H. (1990). Organizational culture: Helping new graduates adjust. Nurse Educator, 15(2), March/April, 26-30.

Walker, R., \& Jeurissen, R. (2003). E-based solutions to support intercultural business ethics instruction: An exploratory approach in course design and delivery. Journal of Business Ethics, 48, 113-126.

Woods, P., \& Barker, M, (2003). Developing intercultural skills for business students. Proceedings of the Effective Teaching and Learning Conference, Queensland College of Art, Griffith University, Australia. 


\section{Biography}

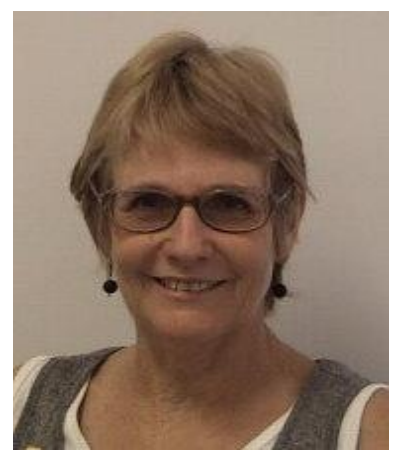

At the time of writing, Dale Mackrell was a lecturer in Information Systems in the Griffith Business School of Griffith University, Brisbane, Australia. She is now an assistant professor in the Information Sciences and Engineering Faculty at the University of Canberra. Her research interests are business intelligence, in particular, the adoption and use of agricultural decision support systems, as well as the alignment between the academic preparation of MIS graduates and the industry expectations of technology intensive organisations. Dale has published several conference and journal papers. 